Article

\title{
Towards a New Paradigm in Water Management: Cochabamba's Water Agenda from an Ethical Approach
}

\author{
Francesc Bellaubi ${ }^{1, *}$ and Rocío Bustamante ${ }^{2}$ \\ 1 Consultant, Prenzlauer Promenade 183, 13189 Berlin, Germany \\ 2 Lecturer/Researcher, Centro Andino del Agua, Universidad Mayor de S. Simón, Facultad de Agronomía, \\ Av. Petrolera Km 5, Cochabamba, Bolivia; Rocio.bustamante.centroagua@gmail.com \\ * Correspondence: bellaubi@hotmail.com; Tel.: +49-176-70749133
}

Received: 23 April 2018; Accepted: 9 May 2018; Published: 14 May 2018

\begin{abstract}
The Cochabamba Water War (2000) is well renowned for being a part of the civil society versus water service delivery debate. From a situation of service privatization, limited access, and an inexistent institutional framework in 2000, the current situation in the Cochabamba Valley faces increasing water scarcity within a weak institutional set up. To alleviate the situation, the government of Evo Morales has been actively funding projects considering an Integrated Water Resources Management (IWRM) but confronting customary water rights in rural communities and thus increasing the level of conflict between water uses. Amid these two water management practices appears the Agenda del Agua Cochabamba (AdA) - the Cochabamba Water Agenda-claiming water as part of the commons and not a resource. This paper explains the paradigm's values behind the conflicting IWRM and water rights' water management practices and analyses the AdA under a governability framework identifying the barriers and drivers for its implementation.
\end{abstract}

Keywords: water management; water paradigm; water governability; water conflicts; Cochabamba

\section{Introduction}

In April 2000, the city of Cochabamba was at war. The cause was due to the contracting out of water services to Aguas del Tunari (a consortium between the British firm International Waters, itself a subsidiary of the construction giant Bechtel Enterprise Holdings (USA) and United Utilities (UK), Abengoa, from Spain and four Bolivian companies) to provide "improved" water services to the city of Cochabamba. Once the previous public water service provider, SEMAPA (Servicio Municipal de Agua Potable y Alcantarillado-municipal potable water and sanitation service), was put up for auction for privatization under the policy of private sector participation (PSP) fostered by the World Bank, Aguas del Tunari was confronted with a situation of low system coverage, poor quality of services, and high tariffs. The citizens' opposition to Aguas del Tunari was on two fronts. The first, and the most well-known, reason was the increasing price of drinking water before any investment was made to improve the quality of the service. However, the second and most important reason was the fact that the management contract was perceived by many citizens as the first step to jeopardizing community water systems that were community managed according to customary law. The main outcome of Cochabamba's Water War was the strong negative reaction from the citizenship regarding the marketization and commercialization of water and the participation of the private sector in water services' management [1-3].

There is a plethora of literature available on water conflicts, water governance, and integrity, as well as on water management and the possible impact on water systems [4-11]. However, there is 
an interesting piece of work that looks simultaneously at different governance frameworks in a reform context with the resulting management practices, together with the impact of performance in Water Service Delivery (WSD) [12]. More specifically, the study refers to the problems derived from PSP in WSD $[13,14]$. Although the research was conducted in Sub-Saharan Africa, similar conditions regarding largely populated and economically vulnerable areas in a situation of water scarcity exist, similar to those of the Cochabamba Valley. The aforementioned research is also interesting, because it goes beyond a mere institutional analysis and emphasizes the resulting management practices when dynamics and asymmetries of power between actors involved in WSD are taken into consideration [15]. Finally, the possible impact of such water management practices on WSD performance has also been studied [16].

According to the opinion of the authors, the point that makes of the Cochabamba an interesting case is the fact that, in addition to improving the situation through institutional reform or by taking a power struggle approach, there was political will to rethink the values that sustain water management. Indeed, the Cochabamba Water War marked a turning point in how water was perceived as an element of sociocultural identity. The rise of Evo Morales in 2006 as president of the Bolivian Pluristate brought a definitive change in policy and enacted institutional reforms to protect local and customary usage rights. The privatization of water sources and management services is prohibited, and priority was focused on social participation for water management and policy decisions, together with the establishment of a water governance system supported by a constitutional framework and legislation integrating traditional, customary knowledge; this was exemplified by the policy of el Desarrollo Integral para el Vivir Bien [Holistic Development for Well-being] [17].

In spite of these changes in the institutional set up, the water conflicts in Cochabamba remained high after the Cochabamba Water War. The term "conflicts over water" is defined as those that arise as part of the hydro-social water cycle [18]. Hydro social cycle is understood as the process by which water arrives from the source to the place of its potential use, treatment, distribution, use of water, wastewater discharge, treatment, reuse or dumping. The hydro-social cycle includes technical, physical, geographical aspects, but also social processes that are crossed by power relations that determine the relationship of social actors with water and with each other. "Conflicts over water imply struggles over resources, over the contents of the rules and the rights, on the authority and on the discourses" [19] (p. 51). Following this definition, a comprehensive analysis of water conflicts registered 270 conflict events in 28 different locations in the Cochabamba Valley between 2009 and 2015 [20]. The causal relationship between these conflicts and water scarcity is not straightforward. Water scarcity is an anthropocentric concept that reflects human preference values, and thus needs to be differentiated from the purely hydrologic concept of water deficit [21]. Water scarcity is defined as an imbalance between supply and demand of freshwater in a specified domain (country, region, catchment, river basin, etc.) as a result of a high rate of demand compared with available supply, under prevailing institutional arrangements and infrastructural conditions [22] (p. 72). Nevertheless, this definition does not consider how, in turn, the effect of water scarcity can subsequently increase water related conflicts. Indeed, the Cochabamba Valley is highly affected by water supply shortages, such as losses in the Cochabamba Municipality water distribution system of around 46\% [23], the pollution of the Rocha River that has an impact on the quality of the water [24], and the persistent low irrigation systems' efficiency at a plot level of around 50\% [25], amongst others. In addition, Bolivia is greatly affected by climate change, which exacerbates droughts and floods [26]. However, the problem underlying this situation of water scarcity is deeply rooted in the different confronting visions about how water is understood and managed [27]. From one side, in Bolivia, and especially in Cochabamba, customary water rights are being claimed by some rural communities as a privilege that grants them undeniable access to water sources and unlimited water use. This water resource appropriation, through misinterpretation of customary laws and transforming property water rights into ownership [28], reflects an attempt to secure water from the different water users, and it is used as a bargaining power strategy to influence political decisions in their favor [29]. The application 
of water rights confronts the weak institutional framework aiming at consensus in water allocation and distribution amongst water users inside the water systems and between these systems frequently located in different municipalities. On the other side, water projects aiming to reduce water stress by increasing the supply (without paying enough attention to the demand side) are implemented by the Plan Nacional de Cuencas (PNC) [River Basin National Plan] under the Ministerio de Medio Ambiente y Agua (MMAyA) [Ministry of Environment and Water] following an Integrated Water Resources Management (IWRM). This is done regardless of social considerations but driven by geopolitical and economic interests and ending, in most cases, in land and water disputes between rural communities and the government. A clear example of this situation is the controversial Misicuni Multipurpose Project (Proyecto Multiple Misicuni (PMM)), a national strategic project with the participation of ENDE (the national electricity provider), situated in nearby Cordillera del Tunari and calculated at around USD $600 \mathrm{~m}$. The PMM aims to increase the drinking and irrigation supply by $3100 \mathrm{~L} / \mathrm{s}$ (a further PMM development is planned if funds are available. This would set the total volume of water production at $6100 \mathrm{~L} / \mathrm{s}$, of which $3900 \mathrm{~L} / \mathrm{s}$ will be designated as potable water, and $2200 \mathrm{~L} / \mathrm{s}$ as water for irrigation, which is estimated to irrigate a total of 5900 hectares and planned to generate a total of $500 \mathrm{GW} /$ year of electricity) in the Cochabamba Metropolitan Area (2000 L/s for drinking water and 1000 L/s to irrigate $5900 \mathrm{Ha}$ ) whilst suppling $120 \mathrm{MW} / \mathrm{h}$. With this purpose, a dam of $185 \mathrm{mill} \mathrm{m}^{3}$ was constructed at $3700 \mathrm{~m} \mathrm{msl}$, displacing rural communities to transfer the water to the Cochabamba Valley [30]. The PMM has been at the center of a number of corruption cases [31]. Figure 1 gives an overview of the Rio Rocha River Basin and Cochabamba Valley considering the PMM.

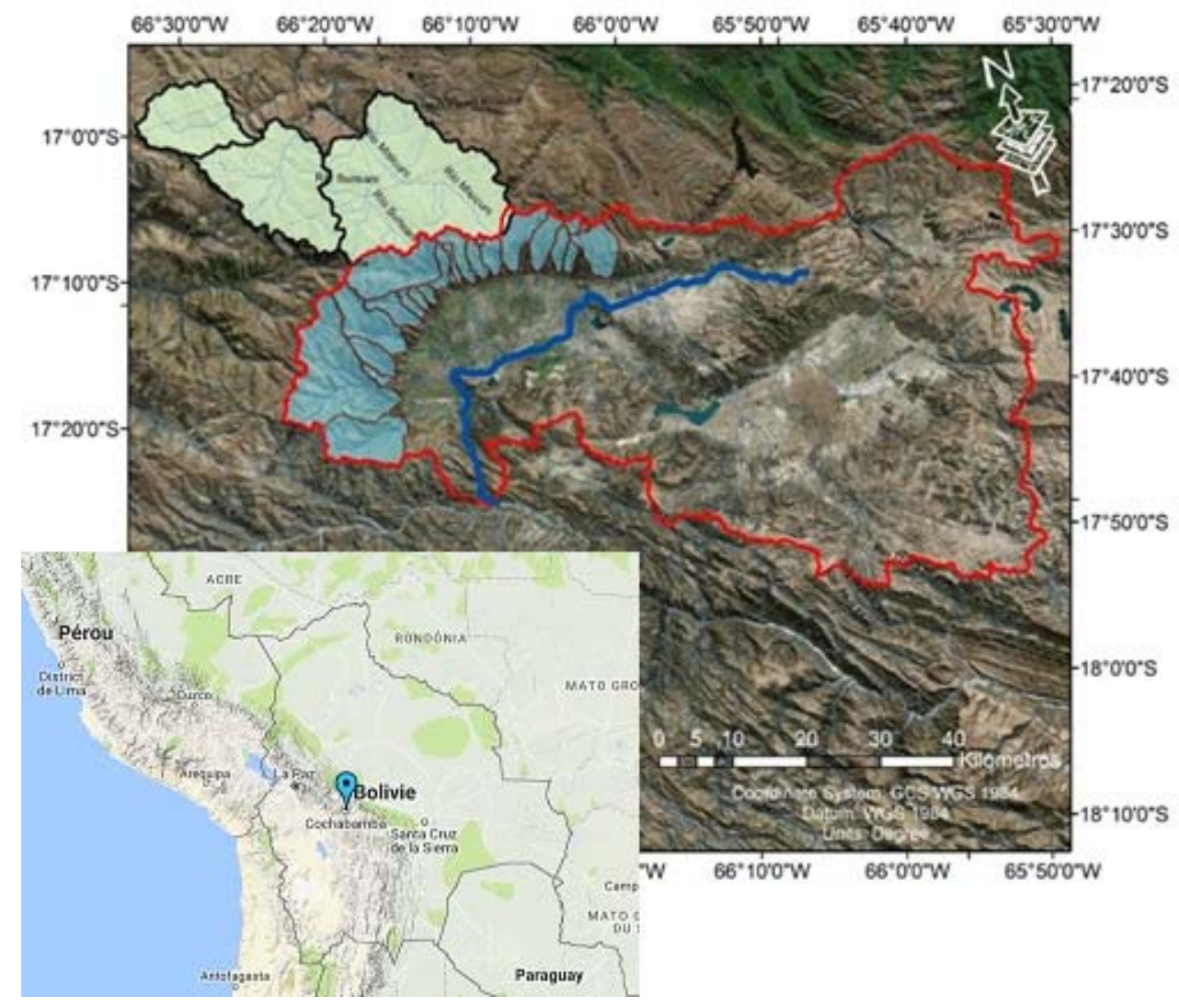

Figure 1. Area of influence of the Rocha River Basin. (Legend: Rio Rocha in blue, Rocha River Basin in red, Misicuni catchments in green, and catchments in use in blue). The River Basin has an area of $3.655 \mathrm{~km}^{2}$ and 1.310.908 inhabitants. Rainfall is estimated between 600 and $622 \mathrm{~mm} /$ year (total rainfall $2144.73 \mathrm{Mill} \mathrm{\textrm {m } ^ { 3 }}$ /year) with a runoff that varies from $8 \%$ to $11 \%$. Drinking water coverage is estimated at $49 \%$ and $62 \%$ for sanitation. Source: Plan Director Cuenca del Rio Rocha, 2015 [24]. 
To confront the current water scarcity situation in the Cochabamba Valley and promoted by the Dirección de Gestión del Agua del Gobierno Autónomo de Cochabamba (Cochabamba Prefecture Water Directorate-DGA), la Agenda del Agua Cochabamba (AdA) (Cochabamba Water Agenda) appears as a politically contested water management paradigm. The Cochabamba Water Agenda is presented as an opportunity to address the challenges in water management in the Cochabamba Department, mainly in the Cochabamba Valley. The AdA proposes a paradigm shift from the values' perspective rather than a transformative change under a governance-institutional approach that focuses on societal learning [32], considering water as a commons and not as a resource through consensual social agreements that must allow the elaboration of a public social policy articulating the public investment process with community initiatives within the scope of the River Basin Management Plans [33].

In this context, the following question arises: what are the drivers and barriers for the AdA to take place? To answer this research question, this paper is organized as follows: Section 2 presents the methodology. Section 3 exposes the AdA in the context of the existing conflicting water paradigms in Bolivia. Section 4 analyzes the drivers and barriers for the implementation of the AdA within a governability framework. Section 5 discusses the paper findings in the context of geoethics. Section 6 concludes with the question of whether a change of values may trigger a reduction of water-related conflicts.

\section{Methodology}

The actual misconception around water crisis is deeply anchored in the myth of climate change affecting water shortage. This is used as an excuse for a number of increasing projects that look at augmented supply and, to a lesser degree, reduce demand. These new projects risk being driven by political interest [34-37]. However, water scarcity is greatly influenced by mismanagement affecting the allocation efficiencies and equitable distribution of water systems [16].

Indeed, water scarcity is mainly a governance problem that is deeply rooted in a crisis of values $[38,39]$. Values determine rules and power distribution amongst actors and organizations, shaping, in turn, management practices that characterize a water paradigm (Figure 2), or, in other words, water paradigms are expressed through water governance models with specific management practices [15]. A paradigm in the Kuhnian sense is a common "accepted" model used by science for the understanding and knowledge of phenomena. Paradigms can be regarded in different categories, and in this paper the authors define water paradigm on the basis of how water is understood or known (epistemology), its objective perception or ontology (water being river, lake, or merely a resource), and how human beings relate to water (axiology) from certain values and principles through water management practices [40].

The authors acknowledge that "Even when paradigms are discussed explicitly, axiology is often forgotten while it should play a major role in the assessment of paradigms for their societal relevance, as well as in scientists' reflexivity about their own work." [41] (p. 2). Therefore, understanding ethics is of crucial importance when looking at water management practices. From a philosophical point of view, ethics refers to the normative study of the values and principles defining the morals or behaviors of the individuals or organizations of a society [42]. In this sense, water ethics is defined "as these underlying principles that influence our own water behavior and our reaction to other people's behaviors" [43] (p. 1). The concept of geoethics summarizes this vision as "Geoethics consists of research and reflection on the values which underpin appropriate behaviors and practices, wherever human activities interact with the geosphere" [44]. However, ethics must converge in universal values for a better world [45]. In this sense, "geoethics" as used from the early 1990s, signifies "the duty of mankind to behave responsibly and become the natural consciousness of the planet" [46] (p. 5). 


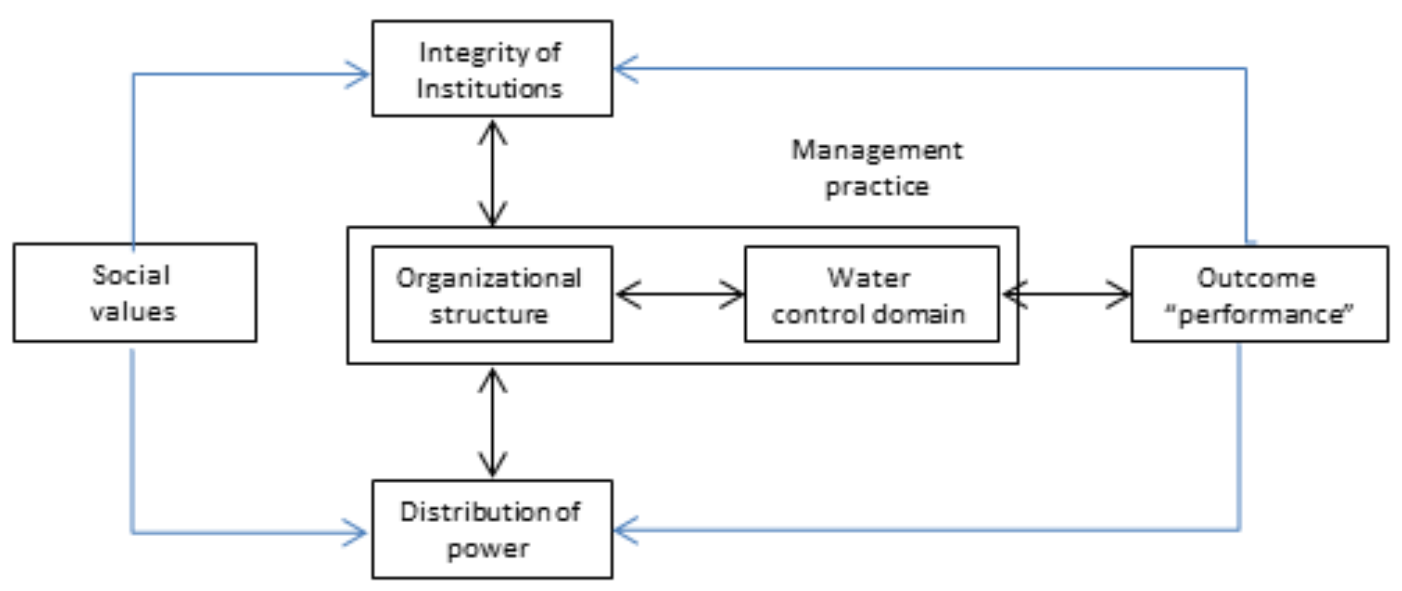

Figure 2. Influence of values on institutions, power dynamics, and management practices.

This paper identifies existing water management practices in Bolivia as the expression of defined paradigms in literature [41]. Management practices differ, because they respond to different paradigm values, because incommensurability of values paradigms cannot be compared, but some paradigm limitations (anomalies) may be highlighted [33]. Furthermore, the paper describes the AdA as a new emerging paradigm from a values' point of view and the water management practices suggested by the $\mathrm{AdA}$. The authors believe promoting change in water policy-making and management should be informed by in-depth research (research-based policy-making and management) under the concept of Adaptive Water Management. (AWM) [47]. (Adaptive Water Management (AWM) seeks to increase the resilience of the water system and reduce vulnerability to uncertainty and change. The AWM has two aspects: (1) The AWM supports the actors involved in water management to understand, adjust, and plan water management projects in situations of uncertainty and (2) The AWM implies learning as a 'systematic process to improve the policies and management practices through learning processes based on the results obtained from previously implemented management strategies' [47].) Therefore, a brief analysis regarding the drivers and barriers for the AdA implementation following a governability framework is presented. Governability relates to qualities of the object of governance (the system-to-be-governed), its subject (the governing system), and the relationship between the two [48]. The governability framework considers the current relationship between the institutional rules framed by the current specific policies (the governing system) and the organizational structures grounded in territorial asymmetries of power for water control that delineate the water political process, also known as hydro-politics (the system-to-be-governed), which result in management practices that the AdA is trying to promote. It has been pointed out that institutional change is not enough to achieve a certain degree of water governability to reduce water conflicts, but there should also be a reshaping of power relations in the department of Cochabamba [49]. In this sense, the authors identify emerging key actors that are able to reshape power dynamics and dialogue processes in redefining new institutions, as the two factors of change to implement the management practices promoted by the AdA [50].

\section{The Emergence of a New Water Paradigm}

La Agenda del Agua Cochabamba (AdA) is set in a turbulent water context as part of a reform process from the institutions themselves. The Programa Manejo Integral de Cuencas (Integrated Watershed Management Program-PROMIC) was a BTC/COSUDE (Belgian/Swiss development agencies partnership)-funded program that lasted from 1991 to 2012. The PROMIC looked at the integrated watersheds' management in the Cordillera del Tunari in Cochabamba. The main objective was integrated river basin management articulated with a productive rural development, integrating the water resources sector with a focus on user participation and consultation. In 2012, 
the Swiss cooperation COSUDE put an end to this program, resulting in the creation of the Watershed Departmental Service-Servicio Departamental de Cuencas (SDC). The mission was to implement the Plan Nacional de Cuencas (PNC) - River Basin National Plan—in the Cochabamba Department, mainly regarding the elaboration of Planes de Cuenca-River Basin Management Plans-under an IWRM approach. However, in the attempt to implement the above-mentioned River Basin Management Plans, the SDC faced two apparently conflicting paradigm approaches: one clearly stated by the PNC as IWRM and the other mainly in the irrigation water sector laws and by-laws based on water customary usage rights.

The PNC clearly approaches water management according to the concept of the IWRM. The authors associate IWRM under a socio-hydrology paradigm [41]. The IWRM presents certain limitations adhering to a utilitarian hydro-engineering 'vision' that continues to see water as a natural resource (either focusing on increasing the offer or reducing the demand), distorts the participation of social actors still strongly conditioned by state actors or captured by community leaders, and focuses on the basin as a management unit that does not take the hydro-social relationships into account thus perpetuating the so-called problems of efficiency and equity in the allocation and distribution of water (There is a vast literature review on why the river basin, as the basic unit to implement IWRM, faced a number of problems [51]. Undoubtedly, water flows beyond the river basin; besides, the IWRM concept applied in a territory is not holistic, since it considers water as the most important resource. Meanwhile, water management is interconnected with other resources, considering the full ecosystem. In this paper, the concept of river basin is extended beyond its hydrogeografic limits and refers to a dynamic hydro-socio-cultural construction. This reality is a complex system composed by the dynamics of power between social actors interacting with the water through institutional artifacts and infrastructures; These interactions constitute a water territory from a cultural point of view defining a specify identity but also beliefs, values and water management practices). Indeed, an interesting point to be considered is whether the problem is a water deficit, either as a result of the balance between the physical supply and the demand of the different "consumer" sectors (uses), or a water scarcity problem resulting from a specific water management in allocation and distribution with regard to real water needs [51,52]. From an axiological point of view, the IWRM is oriented by a utilitarian choice and priorities [41].

Another paradigm of water management is expressed by management practices sustained by water customary usage rights and implicitly recognized by Ley de Riego (Irrigation Law) [53]. For the authors, water rights' management practices relate to a hydrosocial paradigm in which objectives and processes are viewed as social constructs recognizing the role of human interactions and how power and axiology relate to social justice values [41]. Customs are habits or tendencies acquired through the frequent practice of an act (uses). Custom, in law, is "the uniform and uninterrupted way of acting that, for a long period of time, adopts the members of a community, with the belief that this way of acting responds to a legal need, and is mandatory" (Rights of access to water are complex. The "right to water" includes different elements: rights of access, consumption (irrigation, etc.), usufruct rights (for activities that allow one to obtain benefits from water without consumption), management rights and exclusion of users, sanctions, etc.). This text uses the term 'uses and customs' to refer to the elements of management of access and distribution of water, and includes the rights mentioned [54]. In Bolivia, the distinction between right to water and right of water is made. The first refers to access to clean water as a human right, whilst the second considers the access to the water source) [54]. Uses and customs vary over time; management rules are adapted to external or internal changes, as they are eminently practical and operational in nature. They also vary between communities and systems (i.e., spatially). This "adaptation" makes management, based on usage and customs, especially resilient and robust in face of seasonal variations and institutional changes. Changes that affect availability make it necessary to renegotiate new rules and adapt to the water needs. However, the fact that the "rules" are not clearly documented or transcribed allows them to be reinterpreted in favor of specific 
actors and communities who see a source of law (acquired right) in their uses and customs as the reason for a number of conflicts in recent years and being a clear paradigm limitation [20].

Under this situation, the Water Directorate-DGA — was established as a political and normative entity for the whole water sector in the Cochabamba Department. From 2014, the DGA and SDC elaborated and implemented some River Basin Management plans with the help of international donors, which mainly focused on the development of institutional platforms on the basis of existing communal organizations and the reinforcement of local organizations and actors to make the water governability possible in the Cochabamba Department. In parallel to it, the AdA itself was drafted by a group of experts and intellectuals related to the water sector in Cochabamba and close to the DGA during 2012-2013, as a need to give a sustainable, holistic, and comprehensive answer to the water problems in Cochabamba. The key and most interesting point is that the DGA's institutional development is inspired by the Agenda del Agua Cochabamba (AdA), at the same time that the AdA is promoted by the DGA. However, the AdA also receives feedback through social actors and stakeholders in Cochabamba, organized around thematic and territorial platforms that the AdA itself inspires.

At its core, the AdA is a politically contested process to develop a social-public water policy, seeking a social change in the relationship with water, from resource to water as a commons (understood as an equal to other living beings). In this sense, the AdA opposes the concept of water as a resource in some fundamental points. The definition of resource itself as "any good that can provide to the one who owns some utility or benefit in usual terms of economy" is human-centered regardless of the interest of nature, even under a conservationist vision [55]. Another problem is in relation to the resource value and the fact of the incommensurable values as proposed by ecologic economists in regard to natural resources [56]. Furthermore, natural resources constitute the basis of an open economic subsystem, with exchange of matter and energy, which is within a larger system, finite, not growing but capable of developing and being materially closed, such as the geosphere. How and to what extent an open system can grow within another that is closed constitutes a paradox [55]. In the ontological sense, the AdA recognizes water as a common living being with rights, accepting its diversity in the way water manifests itself through rivers, lakes, and streams, etc. [50], in line with the Universal Declaration of Rights of Mother Earth and the policy of el Desarrollo Integral para el Vivir Bien, in which Mother Earth Rights are above Human Rights [17,57]. In this sense, the AdA goes beyond the ontological understanding of water as a commons or commodity, as in both cases water is considered as a mere resource according to access, management, and rights' criteria [58-61].

The AdA compiles these ideas into three basic principles for water management. These values see water as a key element in shaping the collective identity in the Andean culture in rebuilding "communities of water".

- Autonomy. This concept differs from that of decentralization, delegation, or devolution and is understood as the recognition of the relationship between the inhabitants of a territory (communities) and the water.

- Equity. According to the AdA, water is a common living being. This refers to a fair relationship of all humans with water; sharing in an equitable way of distributing the benefits and costs of this relationship under the solidarity principle.

- Responsibility in the relationship with water, not only in terms of efficient and effective use of water based on real needs and availability through service of multiple uses, but with special focus on the different water bodies' needs (rivers, lakes, streams, etc.) through ecologically sustainable yields, thus recognizing the right of present and future generations to a healthy Mother Earth [62,63].

Although briefly, it is also necessary to mention how the AdA may be approached from an epistemological point of view. Whilst the historic ecology somehow reflects part of the AdA ideas on how the water landscapes reproduce the dialogue between humans and water through time and space, 
a missing element is that of identity echoed by cultural geography [64,65]. Cultural geography does not define, per se, an object of study but a way of looking at thought processes under an identity-territorial logic. In this sense, the dialogue of human and water not only shapes landscapes but defines a specific cultural identity and feelings of belonging, being ancient traditions and knowledge and, finally, water management an expression of it.

The concept of cultural geography brings in two fundamental and complementary aspects in studying the AdA as a "new paradigm" of water management. It extends the concept and looks at the dialogue of humans and water through time and space, creating a specific cultural identity in the sense of communities of water $[65,66]$. This dialogue is expressed in the water landscape in both senses: by the hydraulic works that modify the water trajectories and extend water communities and by the water itself overcoming man-made infrastructures by its own physical dynamics affecting the water communities.

\section{Barriers and Drivers in the AdA Management Practices}

This section briefly presents the bases of how the AdA unfolds in a new water new paradigm through management practices as a way to implement the values and principles presented in the previous section.

\subsection{The Community Initiatives and Public Investement as a Management Practice at the Core of River Basin} Management Plans

The starting point for moving the AdA towards its implementation is the interrelationship between available hydrological technical information, social community initiatives, and public investment projects at the municipal/local level. The River Basin Plans are seen as instruments allowing the AdA to operate through consensus agreements between community initiatives and investment projects. These agreements go far beyond the multiple-use water services concept [67] or the benefit-sharing agreements [68], and look at new relationships with the water involving relevant actors and generating social cohesion leading to a strong sense of identity around rivers, lakes, and streams.

The AdA 2016-2020 strategy proposed community initiatives as the central element for the AdA implementation. Initiatives rely on the volunteering commitment of social actors that facilitates the transit of water as a resource towards water as a commons. Accompanying and promoting existing initiatives and facilitating the emergence of new ones are expected to generate a multiplier effect and produce the need to act together (Figure 3).

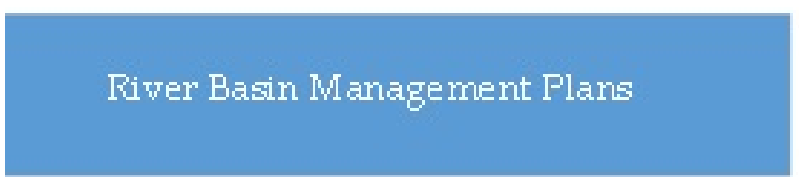

Public investment: projects
Community Initiatives
Impact:

water as a common

New institutions and reshape

of power dynamics

Figure 3. The linked AdA initiatives and public investment within the scope of the River Basin Management Plans.

\subsection{Factors of Change in Implementing the AdA}

This section presents emerging key actors able to reshape power and dialogue processes that may influence the institutional setup as the main two factors of change for AdA implementation considering a status quo of existing rules, organizations and power interests that characterize the current water management. 
The Strategic Framework 2015-2020 of the SDC and DGA establishes that: "The Water Institutions of the Department of Cochabamba is a network of organizations and institutions of the department of Cochabamba, integrated by the political normative and technical instances of the Departmental Autonomous Government (Water Directorate-DGA, and Departmental Service of Watersheds-SDC) and by the social actors who are involved in the water management at a local level".

The DGA recognizes two levels of management authority in the river basins: the technical political authority constituted by the DGA and the SDC, and the networks of local actors directly involved in water management at the system level. Looking at the process of implementation of the AdA, there are four elements to take into account:

- Actors at the political and technical level: Water Management Directorate (DGA) and the River Basin Departmental Service (SDC) of the Departmental Autonomous Government of Cochabamba involved in strategic planning and policy making.

- Local actors involved in local operational water management and project/initiatives' development, such as water communities, municipalities, and municipal commonwealth ("mancomunidades").

- Processes of consultation/negotiation and decision-making between the mentioned actors articulated through agreed rules and norms, and regulations that reflect uses and customs.

- Platforms, networks, forums, etc., to articulate the decisions between the actors and their implementation and follow-up.

According to these considerations, the analysis of drivers and barriers is shown in Table 1. The existence of the DGA and SDC has been one of the main drivers in implementing the AdA. Also, it has allowed the development agencies to have a valid interlocutor for the elaboration of common visions regarding water management in the Cochabamba Valley, as reflected in the AdA. This favorable environment facilitates the attraction of financial resources. It also has an inter-institutional consultation platform that contributes to the exchange of knowledge.

The political situation and the doubts of the departmental political authorities about the process of the construction of the AdA are among the main barriers to the implementation. In addition, there is low organizational capacity and insufficient intra-institutional coordination, which leads to a delay in the positioning of the AdA in the institutional context.

Regarding the dialogue process, the framework of the Bolivian Plurinational State is identified as an opportunity, which prioritizes the water theme, creating the Ministry of Water and Environment, which has the River Basin Plans as a water management instrument under the PNC. These aspects facilitate the elaboration of a portfolio of investments working with the actors involved. Finally, since water is a highly sensitive issue for the Cochabamba people, the AdA is seen as an instrument that can coordinate and facilitate consultation with local practices and knowledge rooted in grassroots social initiatives, creating, and, as mentioned before, a favorable environment for the channeling of new, concurrent financial resources. However, the civil society role is still very uncertain. 
Table 1. Drivers and barriers in AdA implementation. Source: Agenda del Agua Cochabamba, modified by the authors [50].

\begin{tabular}{|c|c|c|c|c|}
\hline \multicolumn{5}{|c|}{ Situation: AdA as an Instrument of Political Orientation of Water Management That Seeks Compromises and Consensus between the Different Public-Private Actors and Civil Society } \\
\hline \multicolumn{3}{|c|}{ ‘Status quo' Variables } & \multicolumn{2}{|c|}{ Factors of Change } \\
\hline Institutions/Rules & Actors/Organizations & Power Interest & $\begin{array}{c}\text { Emerging Key Actors (Motivation } \\
\text { and Abilities) }\end{array}$ & $\begin{array}{c}\begin{array}{c}\text { Dialogue Processes } \\
\text { (Triggers) }\end{array} \\
\end{array}$ \\
\hline $\begin{array}{l}\text { - Water Law in the process } \\
\text { of formulation } \\
\text { - Incomplete regulations } \\
\text { and legislation } \\
\text { - Distortion of the concept } \\
\text { - Sestor Customs" as legitimacy } \\
\text { but not on the overall water wector } \\
\text { - In general there is an overlap of roles } \\
\text { and functions at the institutional level }\end{array}$ & $\begin{array}{l}\text { - National: MMAyA and PNC (development vision } \\
\text { "not in tune" with territorial reality), ENDE } \\
\text { (geo-economic priority), World Bank and } \\
\text { development agencies (not well understood) } \\
\text { - Departmental: Cochabamba prefecture directorates, } \\
\text { farmer's union, PMM, municipal water utilities, } \\
\text { Metropolitan Cuncil (interferences and } \\
\text { political opportunism, "changing") } \\
\text { - Locals: NGOs (looking for a "niche"), } \\
\text { mancomunidad (in "reformulation"), municipalities } \\
\text { ("tied" by "political commitments"), peasant and } \\
\text { irrigating organizations (core of territorial power), } \\
\text { civil society (fragmented and disorganized) }\end{array}$ & $\begin{array}{l}\text { - Little devolution of powers } \\
\text { in institutional terms } \\
\text { - Political influences on major } \\
\text { infrastructure and territorial } \\
\text { investment projects } \\
\text { - "Manipulation" of uses and } \\
\text { customs to maintain "status quo } \\
\text { of control" and hoarding }\end{array}$ & $\begin{array}{l}\text { - DGA as a body with } \\
\text { normative-regulatory functions in } \\
\text { integrated water management } \\
\text { - Commonwealth/Metropolitan } \\
\text { Council/Municipalities as managers } \\
\text { of change "protagonists of } \\
\text { a territorial integrity" with possible } \\
\text { funds management }\end{array}$ & $\begin{array}{l}\text { - Creation of River Basin organizations in } \\
\text { the role of authorities under the PNC } \\
\text { - Increasing but still "diffuse" demand for } \\
\text { greater transparency accountability and } \\
\text { participation in decision-making processes }\end{array}$ \\
\hline
\end{tabular}




\section{Overall Discussion}

The paper provides a reflection of the possibility of overcoming the nature/human divide with respect to the "new" values approach to water management in Cochabamba and, at the same time, taking into account the water-related conflict resolution construct in water management to be turned into a common social vision. This reflection needs to be placed in a broader debate about geoethics and, more specifically, the role of geoethics in education. The goal of geoethics is to suggest practical solutions and provide useful techniques, and also to promote cultural renewal in how humans perceive and relate to the planet, through greater attention to the protection of life and the richness of the Earth, in all its forms [44] (p. 1). Geoethics adopts a holistic vision that goes beyond the dualism between humans and nature [46] (p. 4). Similarly, the AdA does not express a duality but acknowledges water as a common being. Furthermore, the AdA does not understand the relation of water-man from a scientific approach, such as the Gaia theory in which organic and inorganic components of Earth form a seamless continuum - a single, self-regulating, living system [69] or the notion of noosphere as the last stage of the evolution of the biosphere result of the human cognition [70] (p. 1). The AdA seeks a new cultural relationship with water between humans and water that lies in the concept of breeding (uyway in Quichuan). Breeding is the way we acknowledge the Other as being legitimate in equality; thus, breeding is always mutual.

The importance of literacy in geoethics is fundamental not only in promoting new values, as stated by the geoethics' role that allows people to socially participate in the political water debate, but also in highlighting "anomalies" in the existing water paradigms as an ethical duty to create change [71]. It can be expected that geoethics' literacy will increase cultural capital and enhance cultural change to influence values, attitudes, and finally behaviors [72,73]. Indeed, cultural trigger may mark an "inflexion point" in changing paradigms, together with an increasing ecological awareness shared with a globalized world facing the same problems in different realities [74]. Raising cultural capital for cultural change offers an alternative vision of how problems should be approached. In that way, social-equity and ecological sustainability make water management a political issue of public debate.

\section{Conclusions}

In spite of the institutional changes overtaken by Evo Morales' government in favor of water management relying on customary usage rights, management, promoted by the Ministry of Environment and Water based on the concept of Integral Water Resources Management (IWRM), has resulted in water policies that conflict with territorial interests. This situation configures the political arena, where asymmetries of power play an important role, and suggests that the water scarcity that is causing an increase in water conflicts is politically driven and influenced by management approaches that obey different paradigms from an axiological point of view.

From one side, the IWRM, justified by donors pushing for policies to tackle climate change, addresses water scarcity by remaining focused on augmenting supply. From the other side, the government is engaged in a campaign to increase irrigation areas through both bilateral projects and nationally funded projects, such as "Mi Riego" and "Mi Agua", with a focus on more infrastructures to improve water access services to increase the resilience of vulnerable populations that constitute the broad rural support of Evo Morales' MAS party. Besides, there is lack of consensus in the whole project cycle implementation, which increases the tensions between current and potential future users. It is also observed that in the Cochabamba Valley, there is an insufficient commitment from actors who manage and take advantage of water by competing for different uses, such as farmers, industrial and domestic users, and touristic activities. The absence of a water law contributes to the creation of a confused competence framework, including the lack of fulfilment of the roles of some sub-national actors, the dispersion of public and private investments, and limited inter-institutional coordination.

In this context, the Cochabamba Water Agenda (AdA) appears as an opportunity for social change to move from water as a resource towards water as a commons. Recognizing water as a commons means recognizing water as a being with which one lives, accepting the diversity of its expressions in 
rivers, lakes, and streams. The AdA is understood as an on-going, politically contested political process that sits as a new water management paradigm from a values' point of view in which stakeholders seek negotiated agreements to build on a common sustainable vision of water. However, in order to reduce water-related conflict levels, it seems necessary to better articulate the institutional framework and actors' coordination in a way that the power asymmetries are smoothed through conciliation for a new relationship with water in the Cochabamba Valley.

The question remains whether politicians, the public sector, and civil society are determined to enact a paradigm shift that would gain its biggest strength through its capacity to absorb individuals under a common vision; acknowledging that new paradigms are not imposed, but the old ones "extinguish" because of their limitations, it is, therefore, important to expose the anomalies in the existing paradigms. In contrast to solutions focusing on politics and power relationships (dominate and resist) or deliberation and Habermasian dialogues, the authors ponder the role of alternative pedagogical approaches, considering the role of ethics as key to committing to a dialogue with our living Earth Planet, calling for the construction of water historical identities. "There is a great deal of historical evidence to suggest that a society which loses its identity with posterity and which loses its positive image of the future loses also its capacity to deal with present problems, and soon falls apart." [75] (p. 6).

Author Contributions: F.B. is an international consultant. From 2014 to 2017 he gave technical assistance to the Water Directorate of Cochabamba especially in the implementation of the A. R.B. is a Researcher at the Centro Andino del Agua. She has participated in different consultations about the AdA as a water rights expert.

Conflicts of Interest: The authors declare no conflict of interest.

\section{References}

1. Nickson, A.; Vargas, C. The limitations of water regulation: The failure of the Cochabamba concession in Bolivia. Bull. Lat. Am. Res. 2002, 21, 99-120. [CrossRef]

2. Bakker, K. The ambiguity of community: Debating alternatives to private-sector provision of urban water supply. Water Altern. 2008, 1, 236-252.

3. Marston, A.J. Autonomy in a post-neoliberal era: Community water governance in Cochabamba, Bolivia. Geoforum 2015, 64, 246-256. [CrossRef]

4. Ashby, J. Alternative Approaches to Managing Conflict in the Use of Natural Resources. In Proceedings of the International CBNRM Workshop, Washington, DC, USA, 10-14 May 1998.

5. Cap-Net. Conflict Resolution and Negotiation Skills for Integrated Water Resources Management, Training Manual; Cap-Net: Pretoria, South Africa, 2008.

6. Priscoli, J.D. Participation, Consensus Building, and Conflict Management Training Course; Institute for Water Resources, USACE: Washington, DC, USA, 2003.

7. Butterworth, J.; Ducrot, R.; Faysse, N.; Janakarajan, S. (Eds.) Peri-Urban Water Conflicts; IRC International Water and Sanitation Centre: Delft, The Netherlands, 2007.

8. Barret, P.; Gonzalez, A. Societe Civile et Resolution des Conflits Hydriques. In Technical Documents in Hydrology; No. 9; Unesco: Paris, France, 2003.

9. Visscher, J.T. Conflict Mediation in the Water and Sanitation Sector: And How to Reach Solutions; IRC International Water and Sanitation Centre: The Hague, The Netherlands, 2008.

10. UNESCO. Urban Water Conflicts: An Analysis of the Origins and Nature of Water-Related Unrest and Conflicts in the Urban Context; International Hydrological Programme (IHP); UNESCO: Paris, France, 2006.

11. Priscoli, J.D.; Wolf, A.T. Managing and Transforming Water Conflicts; Cambridge University Press: Cambridge, UK, 2009.

12. Bellaubi, F. Corruption Risks, Management Practices and Performance in Water Service Delivery in Kenya and Ghana. Ph.D. Thesis, Institute of Environmental Systems Research, University of Osnabruck, Osnabruck, Germany, 2016.

13. Bellaubi, F.; Visscher, J.T. Water service delivery in Kenya and Ghana: An area-based assessment of water utility performance. Water Int. 2014, 39, 952-968. [CrossRef] 
14. Bellaubi, F.; Visscher, J.T. Integrity and corruption risks in Water Service Delivery in Kenya and Ghana. Int. J. Water Gov. 2016, 2016, 3-4. Available online: http:/ / www.ijwg.eu/pub/2/ (accessed on 23 April 2018).

15. Bellaubi, F.; Boehm, F. Management practices and corruption risks in water service delivery in Kenya and Ghana. Water Policy 2018, 19. [CrossRef]

16. Bellaubi, F.; Pahl-Wostl, C. Corruption risks, management practices, and performance in water service delivery in Kenya and Ghana: An agent-based model. Ecol. Soc. 2017, 22, 6. [CrossRef]

17. Ley No. 300 Marco de la Madre Tierra y Desarrollo Integral para Vivir Bien 2012. Available online: https:/ / bolivia.infoleyes.com (accessed on 25 April 2017).

18. Bustamante, R. Control hídrico y ciclo urbano del agua en la región Andina de Bolivia Ponencia Presentada en la Mesa Temática: ¿Escasez o territorios en disputa? (Water control and urban water cycle in the Andean region of Bolivia). In Proceedings of the Séptimo Congreso de la Asociación de Estudios Bolivianos y el Archivo y Biblioteca Nacionales de Bolivia (Paper presented at the Thematic Table: Shortage or disputed territories? In Proceedings of the Seventh Congress of the Association of Bolivian Studies and the Archive and National Library of Bolivia), Sucre, Bolivia, 29 July-1 August 2013.

19. Zwarteveen, M.; Boelens, R. La investigación interdisciplinaria referente a la temática de «justicia hídrica»: Unas aproximaciones conceptuales. In Justicia Hídrica: Acumulación, Conflicto y Acción Social; Boelens, R., Cremers, L., Zwarteveen, M., Eds.; Instituto de Estudios Peruanos, Fondo Editorial PUCP: Lima, Peru, 2011; pp. 29-58.

20. Antequera, N. Inventario de Conflictos y Acuerdos por el Agua en Cochabamba; Gobierno Autónomo Departamental de Cochabamba: Cochabamba, Bolivia, 2016; p. 72. Available online: http://observatoriodelagua.net/wpcontent/uploads /2016/05/Informe-Final-Conflictos.pdf (accessed on 18 December 2016).

21. Jaeger, W.K.; Plantinga, A.J.; Chang, H.; Dello, K.; Grant, G.; Hulse, D.; McDonnell, J.J.; Lancaster, S.; Moradkhani, H.; Morzillo, A.T.; et al. Toward a formal definition of water scarcity in natural-human systems. Water Resour. Res. 2013, 49, 1-12. [CrossRef]

22. Food and Agricultural Organization (FAO). Coping with Water Scarcity: An Action Framework for Agriculture and Food Security; FAO Water Reports; Food and Agriculture Organization of the United Nations: Rome, Italy, 2012; p. 38.

23. Jaldin, G.M. Situación del Agua en Cochabamba, Bolivia; SEMAPA: Cochabamba, Bolivia, 2000.

24. Gobierno Autónomo Departamental de Cochabamba. Plan Director Cuenca del Rio Rocha. 2015. Available online: http:/ / bibliotecadelagua.sirh.gob.bo/docs/pdf/210.pdf (accessed on 15 April 2017).

25. Prudencio, A. Manejo Integral del Agua en el Valle de Cochabamba; Foro Del Agua De Cochabamba Documento Base; Asociacion De Investigacion Y Desarrollo Andino-Amazonico: Cochabamba, Bolivia, 1998.

26. UNFCCC Bolivia National Climate Change Adaptación Mechanism. Building an Adaptation Strategy to Climate Change; National Climate Change Programme Bolivia/United Nations Framework Convention on Climate Change: Bolivia. Available online: https://unfccc.int/files/adaptation/sbsta_agenda_item_ adaptation/application/pdf/bolivia_rome_poster.pdf (accessed on 20 January 2017).

27. Mollinga, P. IUSF-TIAS Autumn School Course Notes; SOAS, University of London: London, UK, 2015.

28. Theesfeld, I. Introduction to Property-Rights Theory: Concepts, Frameworks and Methods for the Comparative Analysis of Water Governance. Presentations of The Autumn School/Institute of Environmental Systems Research and TIAS and sponsored by the Volkswagen Foundation, Julich, Germany, 28 October-6 November 2015.

29. Cascao, A.E.; Zeitoun, M. Power, Hegemony and Critical Hydropolitics. In Transboundary Water Management: Principles and Practice; Earle, A., Jgerskog, A., Öjendal, J., Eds.; Earthscan: London, UK, 2010; pp. $27-42$.

30. MMAyA. Primera Evaluación en Torno al Nexo Agua-Energía-Seguridad Alimentaria Estado Plurinacional de Bolivia; GIZ: Eschborn, Germany, 2015.

31. Regalsky, P. El Proyecto Misicuni y la territorialidad originaria (TCO) de Ayopaya. Agua para Cochabamba ... y ¿Quién tiene el agua? In La Problemática de la Tierra a 18 años de la Ley INRA; Fundación Tierra: La Paz, Bolivia, 2015; pp. 13-54.

32. Pahl-Wostl, C. Introduction to Water Governance and to Comparative Analysis; University of Osnabreuck: Osnabrück, Germany, 2015.

33. Kuhn, T. The Structure of Scientific Revolutions, 2nd ed.; Chicago University Press: Chicago, IL, USA, 1970.

34. Transparency International (TI). Global Corruption Report: Climate Change; Earthscan: London, UK, 2011. 
35. Water Integrity Network (WIN). Water, Corruption and Climate Change; WIN Expert Consultation; Heinrich Böll Foundation: Berlin, Germany; Water Integrity Network: Berlin, Germany, 2010.

36. Carr, W.; Preston, C. Skewed Vulnerabilities and Moral Corruption in Global Perspectives on Climate Engineering. Environ. Values 2017, 26, 757-777. [CrossRef]

37. Richards, A. Coping with Water Scarcity: The Governance Challenge; Paper PP54, Institute on Global Conflict and Cooperation, IGCC Policy Papers; University of California, Multi-Campus Research Unit: Oakland, CA, USA, 2002.

38. Nickum, J.; Wester, P. An exchange between Ben Crow and Yoram Eckstein on the global water crisis. Water Int. 2014, 39, 774-784.

39. Carrera, J.; Puig, L. Cap A Una Ecologia Integral; Centre d'Estudis, Cristianisme i Justícia: Barcelona, Spain, 2017.

40. Prudencio, J. Introducción a la Teoría de la Complejidad Course Notes; Universidad Catolica Boliviana: Cochabamba, Bolivia, 2012.

41. Wesselink, A.; Kooy, M.; Warner, J. Socio-hydrology and hydrosocial analysis: Toward dialogues across disciplines. Wiley Interdiscipl. Rev. Water 2016, 4. [CrossRef]

42. Camps, V. Breve Historia de la Etica; RBA Libros: Barcelona, Spain, 2013.

43. Groenfeldt, D. Toward a New Water Ethic. Leopold Outlook 2016, 16, 12-16.

44. Peppoloni, S.; Di Capua, G. The Meaning of Geoethics. In Geoethics: Ethical Challenges and Case Studies in Earth science; Wyss, M., Peppoloni, S., Eds.; Elsevier: Waltham, MA, USA, 2015; pp. 3-14. ISBN 978-0-12-799935-7.

45. Camps, V. Los Valores de la Educación, 7th ed.; Anaya: Madrid, Spain, 2000.

46. Bobrowsky, P.; Cronin, V.S.; Di Capua, G.; Kieffer, S.W.; Peppoloni, S. The Emerging Field of Geoethics. In Scientific Integrity and Ethics with Applications to the Geosciences; Gundersen, L.C., Ed.; Special Publication American Geophysical Union; John Wiley and Sons, Inc.: Hoboken, NJ, USA, 2017.

47. Pahl-Wostl, C.; Sendzimir, J.; Jeffrey, P.; Aerts, J.; Berkamp, G.; Cross, K. Managing change toward adaptive water management through social learning. Ecol. Soc. 2007, 12, 30. [CrossRef]

48. Kooiman, J.; Bavinck, M.; Chuenpagdee, R.; Mahon, R.; Pullin, R. Interactive governance and governability: An introduction. J. Transdiscipl. Environ. Stud. 2008, 7, 1-11.

49. Quiroz, F. Diagnóstico Político Institucional Cuenca del Río Rocha; Servicio Departamental de Cuencas: Cochabamba, Bolivia, 2012.

50. Agenda del Agua Cochabamba (AdA). Agenda del Agua Cochabamba (2025); Gobierno autónomo departamental de Cochabamba: Cochabamba, Bolivia, 2017.

51. Butterworth, J.; Warner, J.; Moriarty, P.; Smits, S.; Batchelor, C. Finding practical approaches to Integrated Water Resources Management. Water Altern. 2010, 3, 68-81.

52. Turton, A. Benefit-Sharing as a Vehicle for Effective Water. In Proceedings of the Governance 2008 World Water Week, Stockholm, Sweden, 17-23 August 2008.

53. Ley No. 2878 de Riego. Available online: https:/ / bolivia.infoleyes.com (accessed on 25 April 2017).

54. Coordination SUD. Por Una Justicia Social del Agua: Garantizar el Acceso de las Agriculturas Familiares del Sur al Agua; Comisión de Agricultura y Alimentación de Coordination SUD: Paris, France, 2012.

55. Naredo, J.M.; Parra, F. Hacia Una Ciencia de Los Recursos Naturales; Siglo Veintiuno de España Editores: Madrid, Spain, 1993.

56. Martínez Alier, J. Curso de Economía Ecológica; Red de Formación Ambiental: México, Mexico, 1998.

57. Universal Declaration of Rights of Mother Earth. In Proceedings of the World People's Conference on Climate Change and the Rights of Mother Earth, Cochabamba, Bolivia, 22 April 2010.

58. Bakker, K. The "commons" versus the "commodity": Alter-globalization, anti-privatization and the human right to water in the Global South Journal compilation. Antipode 2007, 39, 393-570. [CrossRef]

59. ICWE (International Conference on Water and the Environment). The Dublin Statement and Report of the Conference; World Meteorological Organization: Geneva, Switzerland, 1992.

60. Ostrom, E. Governing the Commons: The Evolution of Institutions for Collective Action; Cambridge University Press: New York, NY, USA, 1990.

61. Ruf, T. Comprendre le maillage territorial d'un bassin versant, une étape préliminaire pour engager une gestion concertée sur l'eau. In Gestion Intégrée de l'eau au sein d'un Bassin Versant, Proceedings of Actes de l'atelier du PCSI, Montpellier, France, 2-3 Décembre 2003; Le Goulven, P., Bouarfa, S., Kuper, M., Eds.; Cirad-IRD-Cemagref: Montpellier, France, 2003. 
62. Daly, H.E. Toward some operational principles of sustainable development. Ecol. Econ. 1990, 2, 1-6. [CrossRef]

63. Leopold, A. A Sand County Almanac; Oxford University Press: New York, NY, USA, 1949.

64. Crumley, C.L. Historical Ecology: Integrated Thinking at Multiple Temporal and Spatial Scales. In Proceedings of the World System History and Global Environmental Change Conference, Lund, Sweden, 19-22 September 2003; Lund University: Lund, Sweden, 2003.

65. Boelens, R.; Hoogesteger, J.; Swyngedouw, E.; Vos, J.; Wester, P. Hydrosocial territories: A political ecology perspective. Water Int. 2016, 41, 1-14. [CrossRef]

66. Delgadillo, O.; Durán, A. (Eds.) La cuenca hidrosocial: Una aproximación conceptual y metodológica para la gestión del agua en cuencas. In Aguas Arriba, Aguas Abajo: Luces y Sombras de la Gestión Integral de los Recursos Hídricos, Reflexiones Desde la Investigación Aplicada; Centro AGUA-Proyecto GIRH-Programa SIDAGUA-PIEB: La Paz, Bolivia, 2008; p. 469.

67. Van Koppen, B.; Moriarty, P.; Boelee, E. Multiple-Use Water Services to Advance the Millennium Development Goals; Research Report 98; International Water Management Institute: Colombo, Sri Lanka, 2006.

68. Zeitoun, M.; Warner, J. Hydro-hegemony-A framework for analysis of trans-boundary water conflicts. Water Policy 2006, 8, 435-460. [CrossRef]

69. Ogle, M. Gaia Theory: Model and Metaphor for the 21st Century; North American Association for Environment Education: Washington, DC, USA, 2014.

70. Levit, G.S. The Biosphere and the Noosphere Theories of V.I. Vernadsky and P. Teilhard De Chardin: A Methodological Essay; Istituto Della Enciclopedia Italiana Fondata Da Giovanni Treccani: Rome, Italy, 2004.

71. Lacreu, H.L. The Social Sense of Geological Literacy. Ann. Geophys. 2017, 60. [CrossRef]

72. Knott, D.; Muers, S.; Aldridge, S. Achieving Culture Change: A Policy Framework; Cabinet Office: London, UK, 2008.

73. Bourdieu, P. The forms of capital. In Handbook of Theory of Research for the Sociology of Education; Richardson, J.E., Ed.; Greenwood Press: Westport, CT, USA, 1986; pp. 241-258.

74. Tabara, J.D.; Ilhan, A. Culture as trigger for sustainability transition in the water domain: The case of the Spanish water policy and the Ebro river basin. Reg. Environ. Chang. 2008, 8, 59-71. [CrossRef]

75. Boulding, K.E. The Economics of the Coming Spaceship Earth. 1966. Available online: http:/ /www.geocities. com/RainForest/3621/BOULDING.HTM (accessed on 4 February 2018).

(C) 2018 by the authors. Licensee MDPI, Basel, Switzerland. This article is an open access article distributed under the terms and conditions of the Creative Commons Attribution (CC BY) license (http://creativecommons.org/licenses/by/4.0/). 